\title{
Studying the Effective Factors on Quality of Human Sources Training Plans (Case study: Employees of Iran's Saderat Bank- Tehran's West Superintendence)
}

\author{
Mina Jamshidi Avanaki ${ }^{1} \&$ Kolsoom Najafifar ${ }^{2}$ \\ ${ }^{1}$ Department of Management, Central Tehran Branch, Islamic Azad University, Tehran, Iran \\ ${ }^{2}$ Department of Management, Electronic Branch, Islamic Azad University, Tehran, Iran \\ Correspondence: Mina Jamshidi Avanaki, Department of Management, Central Tehran Branch, Islamic Azad \\ University, Tehran, Iran. E-mail: esfehani.mohamad3@gmail.com
}

Received: June 29, 2016

Accepted: July 18, 2016

Online Published: July 20, 2016

doi:10.5539/mas.v10n12p66

URL: http://dx.doi.org/10.5539/mas.v10n12p66

\begin{abstract}
The purpose of this paper is to study the effective factors on quality of human sources training plans. Current research in terms of purpose is applicable and in terms of nature, it is descriptive and correlation kind and in terms of method, it is a survey research. The statistical population includes all employees who work in Saderat Bank of Tehran's west superintendence that the total number was 200 persons. The sample size was selected 131 persons according to Cochran's formula and the sampling method was simple random. In order to collect the data, the researcher-made questionnaire with 37 items in the form of 5-degree Likert spectrum from too high to too low was used. The face and content validity of questionnaire was confirmed by some of the experts and knowledgeable persons. Since Cronbach's Alpha coefficient for the variables of curriculums $(0.875)$, training environment (0.942), work environment (0.759), personality characteristics of trainees $(0.901)$, quality of in-service training plans $(0.867)$ was obtained higher than 0.7 , therefore the reliability of the questionnaire is confirmed. In order to analyze the data, one-sample t-test and two-variable linear Regression with spss software were used. The results indicated the variables of curriculums with $\beta$ coefficient of 0.068 percent, training environment with $\beta$ coefficient of 0.379 percent, work environment with $\beta$ coefficient of 0.762 percent and personality characteristics of trainees with $\beta$ coefficient of 0.241 percent have the power of predicting the dependent variable changes of in-service training plans quality. The adjusted explanation coefficient was 0.980 that indicated 4 independent variables of the research have been able to predict 98 percent of dependent variable changes.
\end{abstract}

Keywords: quality, human sources, in-service training, employees

\section{Introduction}

Training is a kind of learning experience and learning is the change proportional with sustainability which is created in the potential behavior of persons by the effect of experience. This word is applied more in translation of training word, while the real translation of this word is education and the purpose of it is the regular and constant proceeding that the purpose of it is to help the physical, mental, cognitive, moral and social growth or generally the growth of learners' personality aligned with social normalization and help to the fluorescence of the talents (Seif, 1991). In-service training to create learning experience is since the time that person has traversed his employment stages and he is employed in the institution and specialized or professional training will be as a kind of in-service training, an attempt for accurate conformity of person to the vocational features and coordination of him with the organization's needs. Also in-service training is the set of planned training activities for reforming and enhancing the knowledge, skills, attitude and behaviors of organization's members for doing the special tasks and organizational duties (Singh and Mohanty, 2012).

In-service training has been expanded abundantly as a part of the plans for development and excellence of employees in today's organizations. The purpose of codification of training plans in the organizations is to update the forces and employees as the most important company's capitals. Development of organizational human sources causes to promote the goods production and services and also improve it, but certainly the organizational productivity promotion can be known as the most important output of development plans of human sources in 
the organization. In-service training in the organization can have direct and indirect effect on promotion of productivity (Barzegar, Farjad, 2011). The organizations that utilize of knowledgeable and successful managers have understood the necessity of training in the organizations correctly and they consider the development on $\mathrm{d}$ improvement of human sources as one of the organizational necessities. Development and improvement of the organizational human sources requires to identify the training needs proportional with each vocation for the employees of that vocation. Explaining the training needs is in fact the underlying stone of training planning proportional with each vocation for the employees of that vocation (Abdi \& Sharifzadeh, 2008).

In the foundation of in-service training, there is this belief that this kind of training can increase the knowledge and skill of participators and it can make their attitude positive, this kind of training will be useful when the members want to learn and the superintendents want to teach (Haddadnia \& Shahidi, 2010).

Therefore, it can be said that the important point is that the human sources productivity isn't increased only by holding these courses, because training courses entail some costs for the organization. On the other hand, Peter Draker believes that despite of heavy costs, training the work force in a short time puts any retarded country in the category of advanced countries with high productivity, therefore the organizations in addition to pay attention to the tangible and intangible training profits and its costs, with the purpose of promoting the quality level of training plans should strengthen the positive points and reduce the negative and ineffective points of these courses. With regard to the mentioned issues, we see that the first and most important results of applying the trained employees is to increase the quality of plans, and constant vocational training of managers and employees can have effective role in progress of organizational purposes, therefore achieving this important case depends on good quality of training the employees (Hariri \& et al, 2010). With these details, the purpose of this paper is to study the effective factors on the quality of human sources training plans in employees who work in Saderat Bank- Tehran's west superintendence.

\section{The Conceptual Model of the Research}

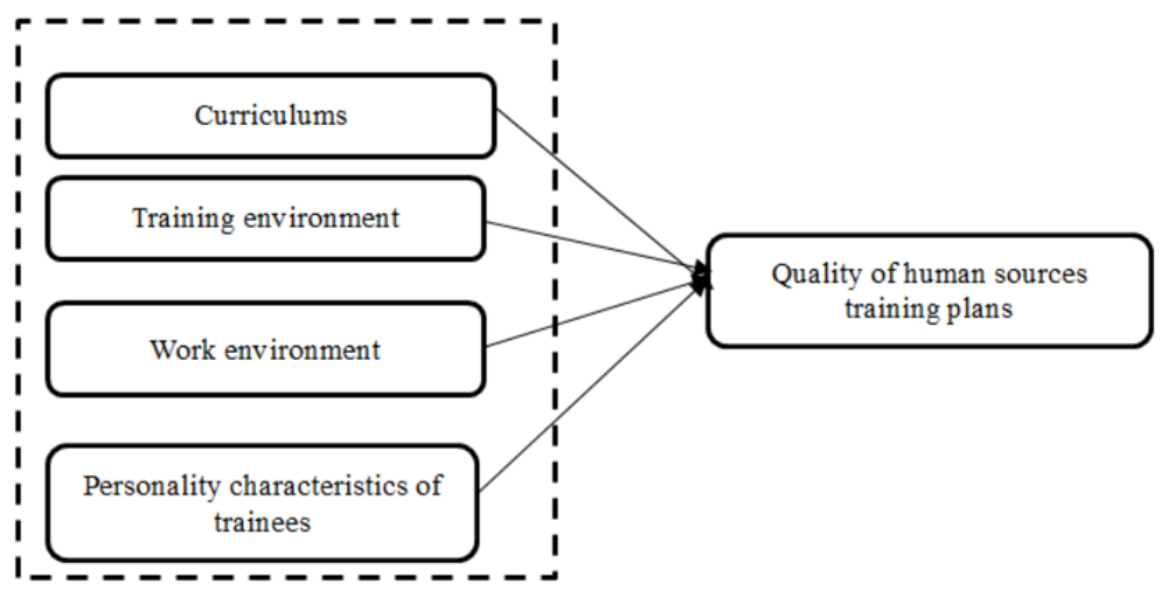

Figure 1. The conceptual model of the research, reference: (Sanjeevkumar \& Yanan, 2011)

\subsection{The Research Hypotheses}

-The curriculums kind (technical and non-technical) has effect on the quality of human sources training in Saderat Bank - Tehran' west superintendence.

-Training environment has effect on quality of human sources training in Saderat Bank - Tehran's west superintendence.

-Work environment has effect on quality of human sources training in Saderat Bank - Tehran's west superintendence.

-The kind of personality characteristics of trainees has effect on the quality of human sources training in Saderat Bank - Tehran's west superintendence.

\subsection{The Empirical Background of the Research}


Matanivet al (2008) did a research entitled "studying the effect of in-service training in development of human sources (in Islamic Azad University, Sari Branch). The results indicated that in-service training courses have been effective on the rate of productivity, job satisfaction, job sustainability and necessary readiness for doing the duties. Also there is meaningful difference between the effectiveness means which have been obtained in two woman and man groups.

Hosseini (2010) in a research entitled "pathology of human sources training" achieved the following results. High-powered and important organizations manage, develop and utilize of all potential ability and talents of their employees in all individual, team and organizational levels and they try to increase the knowledge, skill and abilities of their employees through planned training process based on four steps of needs assessment, training designing and planning, training executive management and also assessment of training (quoted from Monfared, 2010).

Haddadnia \& Shahidi (2010) in a research entitled "studying the view of faculty members of Islamic Azad University about the effect of in-service training of them on training quality of universities" achieved the following results. In-service training to high extent causes the increasing of the scientific abilities, better understanding of students' needs, better using of facilities and equipment, development of needed scientific content, improvement of doing teach duties and improvement of reliability to the university.

Hashemi \& Abbasi (2012) in a research entitled "in-service training as an effective strategy in development of human sources aligned with national production" achieved the following results. Nowadays attention to the human force productivity is one of the most elegant, accurate and perhaps complex works in the management arena and productivity methods in each training environment have relative efficiency and the manager's duty is early diagnosis of these methods in any time and place. Therefore attention to the human sources productivity and enhancement in the organizations is accounted as one of the serious duties of managers that has been considered in this article (quoted from Rahmani, 2013).

Oni et al. (2013) did a research entitled "assessment of training and development effect on Nigeria's banking industry. The results indicated that training has much effect on the development management and un-interrupted developmental policies should be applied for the training and development management in Nigeria's banking industry.

Kijmia et al. (2012) did a research entitled "studying the training effect in productivity. The results indicated, achieving the organization's purposes depends on the employees' ability in doing the duties and conformity to the changeable environment. Executing the training and enhancing the human force cause the persons to be able to continue their activities proportional with organizational and environmental changes effectively and they can add their efficiency. Therefore, training and enhancing constant and planned attempt by management are for improving the employees' competence levels and organizational performance.

Sultana et al. (2012) did a research entitled "training effect on employees productivity". The results indicated that in-service training courses haven't had effect on increasing of vocational satisfaction of employees, but training courses have been effective on increasing of three indexes of the employees incentive to work, employees optimal use of organization sources and employees' skill to do the work. With regard to the mean which was obtained from four indexes, this result has been achieved that in-service training courses is effective on increasing the company's employees productivity (quoted from Farjad and Mollahosseini, 2012).

Irene Fergouson (20090 did a research entitled "the training and development effect on performance and productivity of employees in general sector organizations. The results indicated that training activities shouldn't be done in routine state that all know, rather for better responding, they should be accomplished in a creative form beside other activities in order to be able to help the employees to know their talents and develop their vocational route.

\section{Methodology}

Current research in terms of purpose is applicable and in terms of method, it is descriptive and in terms of information collection kind, it is survey research. The statistical population of current research includes all employees who work in Saderat Bank - Tehran's west superintendence that the total number is 200 persons. The sample size was selected 131 persons according to Cochran's formula. The sampling method was random. In order to collect the data, the researcher-made questionnaire with 37 items in the form of 5-degree Likert spectrum from too high to too low was used. For the variables of curriculums, training environment, work environment, personality characteristics of trainees, quality of in-service training plans in order $15,6,6,5$ and 5 items were regulated. The face and content validity of questionnaire was confirmed by some of experts and 
knowledgeable persons. Since the Cronbach's Alpha coefficient for the variables of curriculums (0.875), training environment (0.942), work environment (0.759), personality characteristics of trainees $(0.901)$ and the quality of in-service training plans $(0.867)$ was obtained higher than 0.7 , it can be said the items have the necessary internal coordination and the reliability of the questionnaire is confirmed. In order to analyze the data, one-sample t-test and two-variable linear Regression with spss software were used.

\section{The Research Findings}

Studying the assumption of the data normality by using of normality test (Kolmogorov - Smirnov)

Table 1. Kolmogorov - Smirnov test results

\begin{tabular}{llll}
\hline & Test result & Meaningfulness level & Conclusion \\
\hline Curriculums kind (technical and non-technical) & 1.543 & 0.217 & Normal \\
Training environment & 1.559 & 0.315 & Normal \\
Work environment & 1.014 & 0.256 & Normal \\
Personality characteristics of trainees & 1.249 & 0.088 & Normal \\
Quality of in-service training plans & 1.675 & 0.076 & Normal \\
\hline
\end{tabular}

According to the table (1) all Kolmogorov - Smirnov fitnesses at meaningfulness level are more than 0.05 namely the research variables have normal distribution, therefore t-test can be used.

\section{Studying the Linear Regression Assumptions}

\subsection{Normality Test (One-Sample Kolmogorov - Smirnov Test)}

Table 2. Kolmogorov - Smirnov test results

\begin{tabular}{|l|l|l|}
\hline & $\begin{array}{l}\text { Quality of } \\
\text { in-service } \\
\text { training plans }\end{array}$ & Standardized errors of predicted value \\
\hline Kolmogorov - Smirnov Z & 0.772 & 0.649 \\
\hline Meaningfulness & 0.590 & 0.793 \\
\hline
\end{tabular}

According to the table (2), all Kolmogorov - Smirnov fitnesses at meaningful level are more than 0.05 namely the dependent variable of the research and remainders have normal distribution and indicate proper fitness of the model.

\subsection{The Errors Independency Test (Durbin - Watson)}

The amount of this test in this research has become 1.845, therefore it can be concluded the errors existing in the Regression equation of this research don't have special correlation and they are independent from each other.

Table 3. Regression analysis results

\begin{tabular}{|c|c|c|c|c|c|c|c|}
\hline $\begin{array}{l}\text { Dependent } \\
\text { variable }\end{array}$ & $\begin{array}{l}\text { Independent } \\
\text { variable }\end{array}$ & $\begin{array}{l}\text { Meaningfulness } \\
\text { level }\end{array}$ & $\begin{array}{l}\text { Regression } \\
\text { coefficient of } \\
\text { Beta }\end{array}$ & Tolerance & $\mathrm{R}_{\text {adj }}^{2}$ & $\mathrm{~F}$ & $\begin{array}{l}\text { Durbin - } \\
\text { Watson }\end{array}$ \\
\hline \multirow{4}{*}{$\begin{array}{l}\text { Quality of } \\
\text { in-service } \\
\text { training plans }\end{array}$} & Curriculums & 0.000 & $* * 0.068$ & 0.567 & \multirow[t]{4}{*}{0.980} & \multirow[t]{4}{*}{1556.015} & \multirow[t]{4}{*}{1.845} \\
\hline & $\begin{array}{l}\text { Training } \\
\text { environment }\end{array}$ & 0.000 & $* * 0.379$ & 0.185 & & & \\
\hline & $\begin{array}{l}\text { Work } \\
\text { environment }\end{array}$ & 0.000 & $* * 0.762$ & 0.428 & & & \\
\hline & $\begin{array}{l}\text { Personality } \\
\text { characteristics of } \\
\text { trainees }\end{array}$ & 0.000 & $* * 0.241$ & 0.256 & & & \\
\hline
\end{tabular}

According to the table (3), the adjusted explanation coefficient is 0.980 that indicates 4 independent variables of the research have been able to predict $98 \%$ of the dependent variable changes. $\mathrm{F}$ number in this equation has 
been obtained 1556.015 that indicates this statistic with obtained amount is meaningful and it is a witness of the independent variables power of the research in explaining the amount of changes and the dependent variable variance. In the analysis of Regression table results, Beta coefficient is used. Beta coefficient is a number between $0-1$, in this form that whatever Beta coefficient is closer to one, there is stronger relation between the independent and dependent variables, if the coefficient is positive, the relation direction will be direct and vice versa.

Finally, Regression equation of this research will be as follows:

$\mathrm{Y}=-1.144+0.068 \mathrm{x}_{1}+0.379 \mathrm{x}_{2}+0.762 \mathrm{x}_{3}+0.241 \mathrm{x}_{4}+0.078$

Hypothesis No. (1) Test: curriculums kind (technical and non-technical) has role in quality of human sources training plans of Tehran's Saderat Bank.

Table 4. One-sample t-test for studying hypothesis 1

\begin{tabular}{|c|c|c|c|c|c|c|}
\hline Hypothesis No & & $\begin{array}{l}\text { Deviation from the } \\
\text { mean }\end{array}$ & $\begin{array}{l}\text { Standard } \\
\text { deviation }\end{array}$ & Mean & & Number \\
\hline \multirow[t]{3}{*}{ Hypothesis No.1 } & & .03678 & .42094 & 4.3664 & & 131 \\
\hline & Reliabil & ty of $95 \%$ & Mean & Meaningfulness & Freedom & $\mathrm{T}$ \\
\hline & High & Low & difference & level & degree & \\
\hline $\begin{array}{l}\text { Hypothesis } \\
\text { No.1 }\end{array}$ & 1.4392 & 1.2937 & 1.36641 & .000 & 130 & 37.154 \\
\hline
\end{tabular}

According to the table (4) with regard to this issue that $p$-value $<0.005$, therefore the assumption of means equality is rejected namely collected data have different means and the amount of mean difference with standard level is equal to 1.366 and this amount of difference is positive number that indicates the mean of responders' view has been considered more than standard level namely the curriculums kind (technical and non-technical) has role in the quality of human sources training plans of Tehran's Saderat Bank.

Table 5. Regression test for studying hypothesis 1

\begin{tabular}{lllllll}
\hline Dependent variable & $\begin{array}{l}\text { Independent } \\
\text { variable }\end{array}$ & $\begin{array}{l}\text { Meaningfulness } \\
\text { level }\end{array}$ & $\begin{array}{l}\text { Regression } \\
\text { coefficient of Beta }\end{array}$ & $\mathrm{R}_{\text {adj }}^{2}$ & $\mathrm{~F}$ & $\begin{array}{l}\text { Durbin - } \\
\text { Watson }\end{array}$ \\
\hline $\begin{array}{l}\text { Quality of } \\
\begin{array}{l}\text { in-service training } \\
\text { plans }\end{array}\end{array}$ & Curriculums & Curriculums & 0.000 & & & \\
\hline
\end{tabular}

According to the table 5, the curriculums variable with Beta coefficient of $0.068 \%$ has the power of predicting the dependent variable changes of in-service training plans quality. Therefore the curriculums component has positive and meaningful effect on quality of in-service training plans.

Hypothesis No. 2 test: training environment has role in quality of human sources training plans in Tehran's Saderat Bank.

Table 6. one-sample t-test for studying the hypothesis 2

\begin{tabular}{|c|c|c|c|c|c|c|}
\hline Hypothesis No. & & $\begin{array}{l}\text { Deviation from } \\
\text { mean }\end{array}$ & Standard deviation & Mean & & Number \\
\hline \multirow[t]{3}{*}{ Hypothesis No.2 } & & .03472 & .39736 & 4.1412 & & 131 \\
\hline & Reliabil & ty of $95 \%$ & Mean & Meaningfulness & Freedom & $\mathrm{T}$ \\
\hline & High & Low & difference & level & degree & \\
\hline $\begin{array}{l}\text { Hypothesis } \\
\text { No. } 2\end{array}$ & 1.2099 & 1.0725 & 1.14122 & .000 & 130 & 32.872 \\
\hline
\end{tabular}

According to the table (6), with regard to this issue that $p$-value $<0.05$, therefore the assumption of means equality is rejected namely collected data have different means and the amount of mean difference with standard 
level is equal to 1.141 and this amount of difference is positive number which indicates the mean of responders' view is more than the intended standard level namely training environment has role in quality of human sources training plans in Tehran's Saderat Bank.

Table 7. Regression test for studying hypothesis 2

\begin{tabular}{lllllll}
\hline Dependent variable & $\begin{array}{l}\text { Independent } \\
\text { variable }\end{array}$ & $\begin{array}{l}\text { Meaningfulness } \\
\text { level }\end{array}$ & $\begin{array}{l}\text { Regression } \\
\text { coefficient of } \\
\text { Beta }\end{array}$ & $\mathrm{R}_{\text {adj }}^{2}$ & $\mathrm{~F}$ & $\begin{array}{l}\text { Durbin - } \\
\text { Watson }\end{array}$ \\
\hline $\begin{array}{l}\text { Quality of } \\
\text { in-service training } \\
\text { plans }\end{array}$ & Curriculums & 0.000 & $* * 0.379$ & 0.980 & 1556.015 & 1.845 \\
\hline
\end{tabular}

As it was indicated in the table 7, training environment component with Beta coefficient of (0.379) $37 \%$ has the power of predicting dependent variable changes. Therefore, there is positive and meaningful relation between training environment component and training plans quality.

Hypothesis No.3 test: work environment has role in quality of human sources training plans in Tehran's Saderat Bank.

Table 8. One-sample t-test for studying hypothesis 3

\begin{tabular}{|c|c|c|c|c|c|c|}
\hline Hypothesis No. & & $\begin{array}{l}\text { Deviation from } \\
\text { mean }\end{array}$ & Standard deviation & Mean & & Number \\
\hline \multirow[t]{3}{*}{ Hypothesis No.3 } & & .04130 & .47269 & \multicolumn{2}{|l|}{4.2061} & 131 \\
\hline & \multicolumn{2}{|c|}{ Reliability of $95 \%$} & Mean & Meaningfulness & Freedom & $\mathrm{T}$ \\
\hline & High & Low & difference & level & degree & \\
\hline $\begin{array}{l}\text { Hypothesis } \\
\text { No.3 }\end{array}$ & 1.2878 & 1.1244 & 1.20611 & .000 & 130 & 29.204 \\
\hline
\end{tabular}

According to the table 8 , with regard to this issue that $p$-value $<0.05$, therefore the assumption of the means equality is rejected namely the collected data have different means and the amount of mean difference with standard level is equal to 1.206 and this difference amount is positive number which indicates the mean of responders' view is more than the intended standard level namely work environment has role in quality of human sources training plans in Tehran's Saderat Bank.

Table 9. Regression test for studying hypothesis 3

\begin{tabular}{lllllll}
\hline Dependent variable & $\begin{array}{l}\text { Independent } \\
\text { variable }\end{array}$ & $\begin{array}{l}\text { Meaningfulness } \\
\text { level }\end{array}$ & $\begin{array}{l}\text { Regression } \\
\text { coefficient of } \\
\text { Beta }\end{array}$ & $\mathrm{R}_{\text {adj }}^{2}$ & $\mathrm{~F}$ & $\begin{array}{l}\text { Durbin - } \\
\text { Watson }\end{array}$ \\
\hline $\begin{array}{l}\text { Quality of } \\
\text { in-service training } \\
\text { plans }\end{array}$ & $\begin{array}{l}\text { Work } \\
\text { environment }\end{array}$ & 0.000 & $* * 0.762$ & 0.980 & 1556.015 & 1.845 \\
\hline
\end{tabular}

As it was indicated in the table 9, this variable with Beta coefficient of (0.762), 76 percent has the power of predicting dependent variable changes. Therefore, there is positive and meaningful relation between work environment component and quality of in-service training plans.

Hypothesis No.4 test: kind of trainees' personality characteristics has role in quality of human sources training plans in Tehran's Saderat Bank. 
Table 10. One-sample t-test for studying hypothesis 4

\begin{tabular}{|c|c|c|c|c|c|c|}
\hline Hypothesis No & & $\begin{array}{l}\text { Deviation from } \\
\text { mean }\end{array}$ & Standard deviation & Mean & & Number \\
\hline \multirow[t]{3}{*}{ Hypothesis No.4 } & & .03627 & .41518 & 4.1618 & & 131 \\
\hline & Reliabili & ity of $95 \%$ & Mean & Meaningfulness & Freedom & $\mathrm{T}$ \\
\hline & High & Low & difference & level & degree & \\
\hline $\begin{array}{l}\text { Hypothesis } \\
\text { No. } 4\end{array}$ & 1.2336 & 1.0901 & 1.16183 & .000 & 130 & 32.029 \\
\hline
\end{tabular}

According to the table 10 , with regard to this issue that $p$-value $<0.05$, therefore the assumption of means equality is rejected namely the collected data have different means and the amount of mean difference with standard level is equal to 1.161 and this difference amount is positive number which indicates the mean of responders' view is more than the intended standard level namely the kind of trainees' personality characteristics has role in quality of human sources training plans in Tehran's Saderat Bank.

Table 11. Regression test for studying hypothesis 4

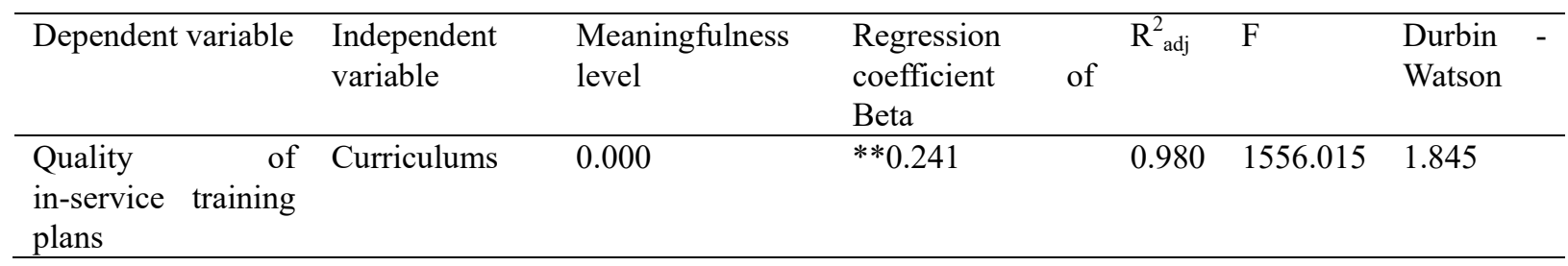

As it was indicated in the table 11, the variable of trainees' personality characteristics with Beta coefficient of (0.241) $24 \%$ has the power of predicting the dependent variable changes of in-service training plans. Therefore, there is positive and meaningful relation between curriculums component and quality of in-service training plans.

\section{Discussion and Conclusion}

Here, a summary of findings is presented:

The results of one-sample t-test with positive standard difference of 1.366 and Regression test with meaningfulness level of lower than 5\% and Beta coefficient of 0.068 indicated the variable of curriculums kind can have positive effect on quality of human sources training plans. Namely with enhancement of curriculums kind, quality of human sources training plans in the bank is improved. This research finding is aligned with the research results of Tansel (1994), Hill (2001) and Boughzala (1999).

Also the results of one-sample t-test with positive standard difference of 1.141 and Regression test with meaningfulness level of lower than 5 percent and Beta coefficient of 0.379 indicated the variable of training environment kind can have positive effect on quality of human sources training plans. The results of this hypothesis are aligned with researches of other researchers that by improving the training environments, the quality of human sources training plans in the bank is increased.

The results of one-sample t-test with positive standard difference of 1.206 and Regression test with meaningfulness level of lower than $5 \%$ and Beta coefficient of 0.762 also indicated work environment variable can have positive effect on quality of human sources training plans.

Finally the results of one-sample t-test with positive standard difference of 1.161 and Regression test with meaningfulness level of lower than 5 percent and Beta coefficient of 0.241 indicated the variable of trainees' personality characteristics kind can have positive effect on quality of human sources training plans.

\section{Suggestions}

According to the result of hypothesis 1, the following suggestions are presented:

-In-service training of Saderat Bank should be planned in order to offer new information to the employees in relation with their works kind.

-In-service training should increase applicable information of employees. 
-In-service training should be in a manner that employees to be able to do their duties correctly.

According to the result of hypothesis 2 , the following suggestions are presented:

-For improvement of in-service training, proper and sufficient training equipment should be provided.

-For improvement of in-service training, the training kind should be provided with practical and workshop method so that through this way, the lessons to be stabilized in the learners' mind better.

-For increasing the training quality, it is better the number of trainees in each class to be selected with proper size.

According to the result of hypothesis 3 , the following suggestions are presented:

-Assessment systems after in-service training should enable us to assess the difference amount of employees' performance with their current status.

-For enhancement of holding in-service training, the training authorities should have mutual agreement with superintendents in the methods of doing work in Saderat Bank.

-Employees should help to each other for understanding new lessons in the work proceeding.

According to the result of hypothesis 4 , the following suggestions are presented:

-The trainees should have active participation.

-Learners should have sufficient incentives for doing individual and gregarious activities.

-Learners should be encouraged for having team work morale.

\section{References}

Barzegar, N., \& Farjad, S. (2011). A Study on the effect of on the job training Courses on the Staff Performance (A Case Study). Procedia - Social and Behavioral Sciences, 29, 1942 - 1949

Boughzala, M. (1999). Returns to Vocational Training in Tunisia. ERF Sixth Annals Conference, 28-31.

Haddadnia, S., \& Shahidi, N. (2010). Studying the view of faculty members in Islamic Azad University about their in-service training effect on universities' training quality. Journal of Training Management and Leadership, Garmsar Branch, 4(4), 35-54.

Hariri, M. H., Mahdian, S., \& Hassanzadeh, A. (2011). Studying the view of central headquarters. Employees of medical sciences university in Esfahan about the role of in-service training on human sources productivity in year.

Hill, E. T. (2001). Post-School-Age Training Among Woman: Training Methods and Labor Market Outcomes at Older Age. Economics of Education Review, 2, 181-191.

Irene Ferguson Laing. (2009). The impact of training and development on worker performance and productivity in public sector organization: a case study of Ghana ports and Harbors authority. Institute of Distance Learning-Knust.

Kijmia, Y., Yukinori, I., \& Keijiro, I. (2012). Assessing the Impact of Training on Lowland Rice Productivity in an African Setting: Evidence from Uganda. World Development, 40(8), 1610-1618.

Matani, M., Hassanzadeh, \& Matani, M. (2008). Studying the effect of in-service training in development of human sources.

Mollahoseini, A., \& Farjad, S. (2012). Assessment Effectiveness on the job training in Higher Education (case study: Takestan University). Procedia - Social and Behavioral Sciences, 47(2012), 1310-1314.

Monfared, N. (2010). Studying the effects and advantages of in-service training in agricultural organizations. Journal of management research of agriculture training, 9 .

Oni, E., Gunu, U. T., \& Ajayi, O. (2013). Empirical study of training and development as a tool for organizational performance. Arabian Journal of Business and Management Review, 2(10).

Rahimi, F. (2013). Teacher training and promotion of vocational competences of chemistry teachers (teachers in-service training), eighth seminar of Iran's chemistry training.

Rohan, S., \& Madhumita, M. (2012). Impact of Training Practices on Employee Productivity: A Comparative Study. Inter-science Management Review (IMR), 2(2). ISSN: 2231-1513.

Seif, A. (2002). Educational psychology, Agah publication. 
Sharifzadeh, F., \& Abdi, F. (2008). Explaining the training needs and in-service training effects on learning of telecommunication's employees of administrative-financial class in general administration of region 2 in Tehran. Management Researches, 1(1), 41-70.

Tansel, A. (1994). Wage Employment Earnings and returns to Schooling for Men and Women in Turkey. Economics of Education Review, 31(4), 305-320.

\section{Copyrights}

Copyright for this article is retained by the author(s), with first publication rights granted to the journal.

This is an open-access article distributed under the terms and conditions of the Creative Commons Attribution license (http://creativecommons.org/licenses/by/3.0/). 